\title{
Sister Ursula de Jesús’ Equal Economy of Salvation
}

\author{
Valerié Benoist • Grinnell College
}

\begin{abstract}
The article examines the diary of Peruvian sister Ursula de Jesús, the first known spiritual journal produced by a black woman in colonial Spanish America. The account, written in first person and consisting of fifty-seven folios, mainly describes sister Ursula's visions and her life inside the Lima convent where she came to be highly revered as a mystic during the seventeenth century. The recognition that this black woman gained was particularly high considering that she lived at a time when most people in the Ibero-transatlantic world associated Afro descendants with the Devil. This fact along with the richness of sister Ursula's spiritual diary has resulted in some merited scholarly attention identifying her work as part of the emergence of a discourse on black religious exemplarity in Lima in the sixteen hundreds. The examination adds to this scholarship by presenting how sister Ursula carefully crafted her vida as a discursive space to argue for a more equal access to the economy of salvation and more solidarity between black catholic women such as herself. The theoretical tools that help guide the analysis are the concepts of economy of salvation, the link between an individual's mystical experience and their dialectical relation to society, and the mediation in textual agency found in spiritual diaries.
\end{abstract}

L ike many Afro-Peruvians during the seventeenth century, Ursula de Jesús was born a slave in the viceroyalty of Peru, Lima, but one accident changes the course of her life and transforms her into a renowned mystic. ${ }^{1}$ In 1617 , her mistress, a wealthy mystic by the name of Luisa de Megarejo Sotomayor, sends Ursula to the Convent of Santa Clara (Lima) and pledges her to the service of Inés del Pulgar, a nun who is related to her. ${ }^{2}$ Ursula remains Pulgar's slave until 1645, but in 1642, while hanging laundry on a platform mounted on top of a well, the platform collapses. It is only after she prays to the Virgen del Carmen that she finds the strength to lift herself. Believing this to be a miracle, Ursula decides to devote herself to God. Her increasingly time-consuming spiritual exercises irritate her mistress, who accuses her of having little time left to perform her more worldly duties. Tensions mount between mistress and servant, and the latter requests to be allowed to leave the convent and find a new mistress. To prevent Ursula's departure from the community, Doña Rafael de Esquivel -- one of Santa Clara's black veiled nuns -- purchases her freedom. Choosing to remain in the same convent, she becomes a donada - a term used to refer to black or indigenous religious servants living in convents (Van Deusen,
"Ursula" 89-94 and The Souls 1-5) . It is in this capacity that she first comes to be recognized as Sister Ursula, and then eventually grows to be highly revered as a mystic at a time when most people in the Ibero-transatlantic world associate blacks with the Devil, and when black women therefore are not allowed to become nuns (Velasquez 388).

As is customary for nuns and mystics in the seventeenth century, sister Ursula's confessor asks her to record her visions and sister Ursula complies by dictating them to other nuns. ${ }^{3}$ Her account is written in first person and consists of fifty-seven folios that mainly describe the mystic's visions and her life inside the convent. ${ }^{4}$ This narrative constitutes the first known spiritual journal of a black Catholic woman in colonial Spanish America. ${ }^{5}$ This fact, along with the richness of sister Ursula's spiritual diary, results in some merited scholarly attention identifying her work as part of the emergence of a discourse on black religious exemplarity in Lima during the seventeenth century. ${ }^{6}$ My objective is to conduct an analysis of Ursula's religious discourse using the theoretical concepts of economy of salvation, the link between an individual's mystical experience and their dialectical relation to society, and the mediation in textual agency found in spiritual diaries. My examination reveals 
how, despite issues of textual agency commonly found in nuns and women mystics' spiritual writing, sister Ursula carefully crafts her vida as a discursive space to argue for a more equal access to the economy of salvation and more solidarity among black-Catholic women.?

\section{SISTER URSULA'S BLACK VIDA OF RACIAL EQUALITY}

Sister Ursula's spiritual journal reveals the limitations in textual agency that usually accompanies vidas; the fact that Ursula dictates her journal to other nuns probably intensifies the process of mediation that typically accompanies this kind of confessional writing. ${ }^{8}$ Indeed, like other nuns and mystics, sister Ursula does not choose to tell her story. Instead, she is obeying her confessor's request to record her mystical visions and experiences. Confessors often order nuns and mystics to compose their spiritual diary because they want to be persuaded of the women's exemplarity and special standing with God (Gunnarsdóttir 10). These writings allow confessors to regulate their religiosity (Donahue 231). Because of these two different purposes, women write from a position of strength and weakness, and they develop narrative strategies for both. Some of the "stratagems of strength" include drawing legitimacy through the women's mystical union with God and claiming that God, the Virgin, or a Saint speak through them (Arenal and Schlau 25-29). Other important strategies of authorization reference Santa Teresa's words and reconfirm the legitimacy of the "mother tongue" by associating their writing with maternal roles, in particular with the Virgin Mary (Saint Teresa of Avila 25-32).9 They also combine those narrative devices with "stratagems of the weak" such as a lack of agency, an affirmation of inadequacy, and a discourse of self-deprecation (Gunnarsdóttir 10, 25)..$^{10}$ Because sister Ursula does not write her vida herself, but instead dictates it to other nuns, her process of textual agency is even more complicated. She first has to craft the narrative of her spiritual life considering that her confessor will use it as a tool to assess her religiosity. Moreover, in her case, the nuns who serve as scribes are another intermediary who also has some agency on her text when deciding how and what to transcribe, and how to best make it fit the form of a conventional vida.

At first sight, sister Ursula's spiritual journal fits well vidas' conventions as it includes a summary of her visions, one of the two most common topics of these writings. It also contains the typical "stratagem of the strong" of the woman's union with God and combines it with a discourse of lack of agency. When describing her visions, she specifies: "when I ask those questions I do not do so because I want to but, just as soon as I see them, they speak to me without my wishing it to happen, and they make me speak without wanting to... I should thank God for the gifts He had given her..." (Van Deusen, The Souls 80). ${ }^{11}$ By stressing that God has given her "the gifts", the text positions Ursula as a woman with special standing with God. Yet, at the same time, by emphasizing that it is not her choice to "see" visions or to "speak" her own words, it also underscores her lack of agency and control over what she is asking and saying. ${ }^{12}$ More specifically, the vida contains the common notion where female mystics' bodies are understood as "readable spaces", places where God can communicate through and where the mystics can find refuge from the scrutiny of their confessors (Van Deusen, "Reading" 5-16). Among the more famous of these mystics, Saint Teresa of Ávila represents herself as a humble servant of God whose body God selected as a conduit of His will and word. In The Way of Perfection, she insists on the importance of mortification and suffering of the human body in order to reach complete abandonment to God: "Let us remember our holy fathers of the past... What suffering they endured!.. Do you think they were made of steel? Well they were as delicate as we. And believe, daughters, that when we begin to conquer these wretched little bodies, we will not be so troubled by them... abandon yourselves totally for God" (81). She also stresses that humility needs to accompany body detachment and suffering: "Here true humility can enter the picture because this virtue and the virtue of detachment it seems to me always go together" (76). Insisting on body detachment, humility and suffering of the body helps Saint Teresa gain some protection from the accusation of heresy in her position as a woman mystic in the early modern period in Spain. It provides her a way to distance herself from her female body, which is perceived as sinful and dangerous (Arenal and Schlau 29-30). Since Saint Teresa is the best-known model for colonial women's vidas, many nuns and women mystics adopt her language.

Following Saint Teresa's example, sister Ursula's vida underlines the importance of humility, self-deprecation, and suffering as conditions to obtain true religious exemplarity and union with God. The text calls attention to sister Ursula's humility when other nuns treat her badly in her convent: "On Wednesday morning, doña Antonia de Serrantes sent her slave to ask me to cook for her. I told her black slave, 'Go with God, your owner only remembers me to give orders'. But then, I called her again to do what she asked me" (Van Deusen, The Souls 96). It also lays emphasis on her self-deprecation when sister Ursula states that she does not deserve salvation: "I hurriedly asked Him for His blessing, although I know very well I did not deserve it. I deserve to go to hell" (The Souls 97). As importantly, it describes the suffering she endures to get closer to God when she performs acts such as "cleaning out the drainage ditch in the infirmary" where she gets "spattered and soiled" (The Souls 87). Finally, it establishes that sister Ursula finds "solace" in doing these painful acts because she does them for God (The Souls 87). The voices from purgatory in her visions reinforce that her torment will bring her closer to God: "the voice said, 
You did such dangerous and extremely difficult tasks, all for God. It will be seen then how good it is for us, and how grateful He is" (The Souls 87).

However, sister Ursula's vida also differs from more conventional ones by defining her blackness as an essential ingredient in the construction of her trope of suffering as imitatio Christi. When depicting that a particular nun is constantly scolding her, her text explains that sister Ursula turns to God to find the strength to endure her suffering: "I go to our Lord and ask Him to give me patience, teach me how to suffer for others, and grant me peace of mind so that I do not criticize another in my heart." (The Souls 104). When insisting on her willingness to endure pain, and asking God to help her to become better at it, the vida is employing a trope that Saint Teresa and Saint Rosa of Lima already used to underscore their special connection with God. What is different in this narrative though is that the first quote is immediately followed by: "I am such a bad black woman" (The Souls 104). The text therefore closely connects sister Ursula's abnegated torment not just to her female body, as Saint Teresa and Saint Rosa had previously done, but to her black female body, a radical shift from the discourse usually found in vidas.

An even more notable difference between sister Ursula's vida and customary nuns' spiritual diaries is the inclusion of blacks as members of purgatory and heaven. In many of her visions, sister Ursula recounts former conventual AfroPeruvian servants approaching her from purgatory and asking her to intervene with God for their entrance into heaven. Her description of Afro-Peruvians in purgatory is audacious, since in seventeenth century Peru, most readers consider the idea of blacks going to heaven upon death surprising and unlikely. ${ }^{13}$ Probably aware of this general perception, sister Ursula portrays herself in her spiritual journal as uncertain on the topic. She asks a black woman who is in purgatory the following question: "I asked whether black women went to heaven and she said if they were thankful and heeded His beneficence, and thanked Him for it. They were saved because of his great mercy." (The Souls 80).

Even though the trope of the blacks' redemption and salvation is bold, especially coming from a black woman, it has already been proposed in a few religious writings, such as Alonso de Sandoval's treaty on African slavery. Alonso de Sandoval is a Jesuit priest who lives and serves in Cartagena de Indias, a major slave trading port entry, and hence, as a missionary, Sandoval has ample contact with African slaves. He is the author of the first book on African slavery in colonial Latin America, a manuscript originally titled De instauranda Aethiopum salute (1627). Sandoval believes that the Apostles preached in Africa before the arrival of the Europeans and that the Jesuits need to help Africans return to their lost Christian state. Hence, he hopes that his book would encourage other Jesuits to join him in his work of preaching and baptizing slaves (Von
Germeten, "Introduction" xv-xxiv). In his treatise, Sandoval also proposes that black slaves should endure their slavery with submission because God sent them corporal pain as an avenue of redemption (75). Indeed, many of the time's biblical scholars believe that blacks stem from a malediction, and that the color of their skin and their slavery is God's punishment to Ham for exposing Noah's nakedness (Carrera 11; Martínez 158). ${ }^{14}$ By accepting their torment and imitating Christ's abnegated suffering on the cross, black slaves free themselves of the sins of their race and enter heaven..$^{15}$

While this portrayal of black Catholics as members of heaven coincide with Sandoval's writing, it conflicts with the more common written characterizations of blacks in religious writings. In their vidas, when nuns describe their temptations of the flesh, they often report the Devil appearing to them as a black man (Brewer-García 10). Saint Teresa herself describes being attacked by an "abominable little black man" in her spiritual autobiography (quoted in 340). ${ }^{16}$ Religious paintings replicate the same idea. For example, in an eighteenth-century painting of Saint Rosa, the attributed author Miguel Cabrera represents the Devil as an enormous black man who pulls Saint Rosa towards his chest (Jaffary 119). Therefore, by making black Catholics central characters of her spiritual journal and characterizing them as capable of salvation, the text distances itself from conventional religious representations of Afro-Peruvians as a group associated with immorality, and instead poses their equality in the afterlife. In it, black Catholics who have not committed irremediable sins, go to purgatory like other Christians: "I said, 'How is that such a good black woman, who had neither been a thief nor liar, had spent so much time in purgatory?' She said she had gone there because of her character, and because she slept and ate at the improper time" (Van Deusen, The Souls 80). ${ }^{17}$ The black Catholics, such as the convent's slave in the quote above, are in purgatory because they are purging their sins through terrible torments, a purgation which eventually allows them to enter heaven. As the diary indicates, despite the suffering, purgatory is a space preferable to Earth because of its purifying nature: "Despite the terrible torment, those in purgatory would never wish to return here, even as lords of the land -because of the danger of losing God" (The Souls 113).

Sister Ursula's spiritual journal also depicts God as one who perceives and treats Afro-Peruvians as equal to His other children. God considers all humans His children, as when Ursula asserts: "Although He raised us as different nations the will of blacks and whites is the same. In memory, understanding, and will, they were all one. Had He not created them all in His image and likeness and redeemed them with His blood" (The Souls 151). Since Africans and their descendants are His Children, God treats them equally: "the voices told me how much in particular the insignificant and humble ones of this house please God. Florencia Bravo and Antonia de Christo are outcasts, and no one pays any 
attention to them. The first one is a wretched mulata and the other a blind, black woman." (The Souls 93-94). God is portrayed as differing radically in His treatment of Africans and their descendants from that of sister Ursula's own religious community. Indeed, by dismissing Florencia and Antonia and not paying attention to them, her convent replicates colonial society's marginalization of Afro-Peruvians. The text therefore subtly establishes that the behavior of those governing her religious community goes against God's example.

While the Peruvian Catholic Church does not generally promote the idea that God sees blacks and mulatos as equals to His other children, two other clergy men from Lima share this conviction and include a similar language of racial equality in their texts. It is worth pointing that, by the seventeenth century, Lima is a uniquely black city, and that maybe as a result of that presence, it also is a particularly welcoming city for religious black figures; by 1636, the Africans and their descendants reach 54 percent of the whole population (Bowser 339, 341). Lima becomes the religious capital of the viceroyalty of Peru and seat of the Archbishop and Holy Office of the Inquisition in the region. The city is also the hometown of Saint Martín of Porres (1579-1639), who later becomes the first mulato saint in the Americas (Tardieu 633). Lima houses a large number of religious orders, and ten percent of the city's inhabitants are members of a monastic or conventual order (Sánchez-Concha 320; Van Deusen, The Souls 7).

The two contemporaries of sister Ursula, both priests in Lima, argue that Afro-Peruvians are as worthy of salvation as those possessing purity of blood. The first clergyman, Diego de Córdoba y Salinas, like Ursula, is a Franciscan. He publishes his chronicle about the Franciscans of Peru in 1651 and in it includes the life account of sister Estephania, a mulata descendant of a slave mother and a Spanish father. Sister Estephania professes as a beata of the Order of the Franciscans and vows to live a holy life (Córdoba y Salinas 189-191; Wood 290) ${ }^{19}$ Córdoba's biography on Estephania, titled Life and Death of the Humble Mother Estefania de San Joseph, Professed from the Third Order of our Father, S. Francisco (1651) echoes the idea that based on their merits, blacks can obtain salvation as much as whites: ${ }^{20}$

...in the court of Heaven, where only merits are considered, who is noble and who is not are equally rewarded; the rich man and the poor one; the black and the white man when their deeds deserve it, because as Saint Paul said, writing to the Romans, God ... does not exclude anyone, He calls everyone to His house and He invites all to His wedding. He honors the merits of the Greek, the Jew, the White, and the Black and He receives them in His favors. This was very well verified with mother Estephania of Saint Joseph.... (949)
By underscoring that God invites his children into heaven, not based on their race or casta but on their religious merits, Córdoba constructs a compelling argument about the religious exemplarity of his Afro-Catholic subject very similar to the discourse about "blacks and whites" being "all one" in their potential for salvation found in sister Ursula's vida (151).

Also published in 1675, is Bernardo de Medina's hagiography about Saint Martín de Porres (1579-1639), a mulatto Dominican lay brother from Lima, Peru, who dedicates his life to the poor and becomes the first mulato to be beatified in the Americas in 1837. In his hagiography, Medina argues that Porres "was pardo, as they say, not white in color as everyone admires. But God, who does not consider accidents of color, but only the merits of the subject, makes no exception of persons, but cares equally for everyone" (quoted in Wood, "Chains" 174). Like Córdoba, Medina insists that God judges His children on their merits and not their skin. Because of her vision about Afro-Peruvians in purgatory, sister Ursula joins the few members of the Peruvian clergy who believe that black Catholics can be equal in their religious merits to white ones. Aligning her language to Córdoba's and Medina's religious rhetoric is particularly important for sister Ursula since she is presenting her spiritual diary to her confessor from the position of a marginal Afro-Peruvian woman, whereas Córdoba and Medina write from a much more authoritative position as white male Peruvian clerics. For the nuns who are serving as the transcribers of her oral spiritual diary, and who themselves live and write under the patriarchal umbrella of the colonial church, framing this discourse as part of the larger male ecclesiastical rhetoric of Córdoba and Medina is safer as well.

Even with the precedents of Córdoba and Medina, recording visions of blacks in purgatory is audacious, and so the diary also insists that sister Ursula's work was consistent with the values left by the founders of her order:

Another time, after I had taken communion the voices told me to commend the spirit of a black woman to God. She had been in the convent and had been taken out to be cured because she was gravely ill but died a few days later. This happened more than thirty years ago, and I had forgotten about her as if she had never existed. I was frightened and thought to myself, "So long in purgatory?" The voices responded, For the things she did. Here, the voices led me to understand that she had illicitly loved a nun and the entire convent knew about it, but that my father, Saint Francis, and my mother, Saint Clare, had gotten on their knees and prayed to our Lady to secure the salvation of that soul from her Son. That is because His house is in good faith. (88)

In her role as a supporter of these subaltern members of her society, sister Ursula is characterized as a true follower 
of San Francisco and Santa Clara, the founders of her order. Both San Francisco and Santa Clara strongly predicate that no brother or sister should have control or authority over another one, regardless of class (Lachance 70). By citing their example and aligning her conduct to that of the father and mother of the Franciscan order, sister Ursula's work in favor of the marginalized Afro-Catholics of her community is framed as one of the tenets of her order. Moreover, by including the example of San Francisco and Santa Clara kneeling to secure the salvation of a black sinner, her work is legitimized as an intermediary of salvation of the African blood community.

\section{AN ALTERNATIVE ECONOMY OF SALVATION}

When further examining sister Ursula's work on behalf of black women's salvation, religious scholar Richard Woods' theory that the evolution of an individual's mystical experience is linked to the individual's dialectical relation to society may prove useful as it reveals that the service that sister Ursula performs for the community of black Catholics can serve a social dimension (158). Indeed, by looking at the mystical experience not as a purely inner experience but as one that connects the mystic with a wider community, some scholars such as Janet Ruffing are able to avoid the separations between "contemplation and action, theory and practice, mysticism and ethical behavior" (2). A consideration of sister Ursula's mystical experience under that light allows for her spiritual journal to be read as a call for social reform. Since sister Ursula is herself a black Catholic woman servant in her conventual community and a subaltern in her society at large, her visions may replicate her dialectical relation to her society. More precisely, they may call attention to the essential service that members of African descent perform in the convent and its larger community, as well as their service to God, and the social and ethical needs for a change to their unequal access to the economy of spiritual salvation. ${ }^{21}$

In the seventeenth century, the economy of spiritual salvation is clearly more accessible to the wealthy. The economy of salvation can be defined as the accumulation of acts of piety, prayers for indulgence and for the soul's salvation. These can be purchased through donations or money, and serve as remedies for a spiritual debt that the individual acquired through his or her sinful conduct while alive. The access to this economy of salvation open to families and friends of the departed is intrinsically connected to their financial means. Richer individuals have more time to pray, and more money for charity and masses. The wealthy also have better access to indulgences and can devote themselves more easily and efficiently to saving the souls of their departed ones and expediting their entrance into heaven (Fogelman 1-26).
As Jacques Le Goff demonstrates, the concept of purgatory is born at the end of the twelfth century as a third space between hell and heaven. It is meant to give an afterlife space to people who are not saints (and who therefore cannot go directly to heaven). In purgatory, the souls of those who have sinned, but are not irremediably condemned, can find salvation (Rodríguez 195). The creation of purgatory by the Catholic Church responds to the new needs created by the transition from a feudal to an incipient capitalist economy that transforms salvation into a series of arithmetic operations (Mártinez i Alvarez 47). As a consequence of the birth of the notion of purgatory as an economic transaction, starting in the thirteenth century, the relationship between the society of the living and the dead drastically changes. Families or friends of the dead begin approaching nuns requesting that they pray for their souls (Rodríguez 279). By the early modern era, it becomes common for families to intervene financially in an attempt to alleviate the suffering of their departed ones and to accelerate their entrance into heaven. Some of the most commonly used methods are the purchase of indulgences and masses (Sánchez-Concha 319; Van Deusen, The Souls 36).

In the spiritual journal, through her mystical visions, sister Ursula's actions on behalf of the impecunious black women can be seen as a call for a more equal access to the economy of salvation. The fact that many of the departed ones who contact sister Ursula from purgatory are black Catholic women who were marginalized inside and outside the convent, and consequently did not belong to the rich and powerful communities who could afford to financially participate in this economy of salvation, constitutes an important element of her mystical experience. Sister Ursula's role as intercessor in their favor serves the social role to resist the inequality of the economy of salvation. Whereas in colonial society the departed black Catholics are quickly forgotten and do not have rich families or friends who can pay for masses and prayers or provide church donations on their behalf, they can rely on sister Ursula who works hard on their behalf. Sister Ursula intercedes with equal fervor for all members of her society-men and women, poor and rich, black and white. She offers to suffer for well-known deceased figures, such as the friar who "appears and asks that I commend his spirit to God." (Van Deusen, The Souls 79). Similarly, she intervenes for elite women, such as doña Polonia who "had endured terrible suffering" (The Souls 82). Yet, she serves equally well the marginal and forgotten women, such as the black and the mulata servants who spent their lives serving others (The Souls 82, 91).

In most of these appearances, the text underscores that sister Ursula and her religious peers have completely forgotten the African descent women who request her service with words such as "had no one who would remember her" (The Souls 82) or "one of the things most forgotten for me in this word" (The Souls 80). Since society 
has completely forgotten those approaching her, it is highly likely as well that nobody is financially contributing to the economy of their salvation. By breaking that pattern, sister Ursula infringes on the economy of salvation that prevails in colonial Lima during the seventeenth century. She offers an alternative method to counteract the financial contributions for salvation, one that requires no money or elite position in society, and one that therefore does not support the privileged access of the rich to salvation.

\section{A NEW BLACK WOMAN"IMAGINED COMMUNITY” BASED ON SOLIDARITY}

By detailing sister Ursula's work on behalf of the black women incapable of contributing to their economy of salvation, the spiritual diary also presents her as advocating on behalf of a community of African descendants and calling for a more equal economy of salvation based on solidarity amongst black women. Mixing her mystical experience with a socio-political discourse is not a radical departure since other mystics, such as Saint Teresa, have already done so based on their own social identity. As Alison Weber successfully demonstrates, Saint Teresa wrote for a dual audience: male readers who were expected to scrutinize her writings and fellow nuns. She therefore constructed a dual rhetoric for her different readers. She suggested that learned men have more important concerns and therefore should perform a cursive reading of her text. At the same time, she encouraged nuns, her true community of readers, to perform a close reading of her text, which introduces them to an "impassioned defense of the spiritual rights of women" through a "rhetoric of solidarity" $(82,84)$. Through her visions, sister Ursula's vida advocates for similar spiritual rights and concepts of solidarity for black women. Indeed, by serving as an equalizer in the access to spiritual salvation at the service of the African descendant community, it constructs a more inclusive community of black Catholic women based on the Christian principles of equality and solidarity.

Interestingly, the principles behind this alternative model of access to salvation on earth also parallel the founding principles of cofradías in colonial Peru. Cofradías are one of the few European institutions that subaltern groups appropriated to fulfill their own needs (Vega 137). Cofradías are religious and economic guilds that originated during Roman times and spread throughout Europe during the Middle Ages with an objective to form communities of solidarity (Black 8; Corilla 18). Cofradías arise in Spain during the twelfth century, and flourish during the fourteenth and fifteen centuries. In time, they mainly become religious guilds with complex and varied relationships with orders that are imported to colonial Latin America. There, they also become places of formation and solidarity for sub-ethnic communities for the entire society, including indigenous and
Afro-populations (Lockhart 290). In colonial Latin America, cofradías serve important economic and social functions that center around the concept of solidarity amongst people of the same ethnic community. Economically, they are communities of financial support where members can secure loans from other members of their community (Vega 138). Two main values of cofradías include cooperation and high solidarity amongst members; thus, they also form a community that empowers them socially in their larger colonial society (Vega 140-149).

By 1619, Lima is home to fifteen cofradías of black Catholics, all patronized by religious orders. Six of those are exclusively composed of black members. Three only welcome mulatos, and six include both mulatos and blacks (Corilla 20). These cofradías provide support for their community and help the inclusion of their members into aspects of the hegemonic culture, such as religious processions (Sánchez 21). At the same time, cofradías also foster a strong sense of unified and unique African descent religious identity by creating their own brown representation of Christ. However, even though blacks and mulatos have their own religious and social communities, which in theory are supposed to work on the principle of solidarity, in practice the black and mulato cofradías often face internal divisions and practices of exclusion. Since holding a leadership position inside a cofradía is often the only recourse available for blacks to achieve power and recognition, members of the same community often fight for the highest administrative positions. Ironically, these institutions reinforce the differences of power between free pardos, ladino slaves, bozales, blacks, and mulatos, and hence replicate the hierarchies established by the colonial society (Corilla 23-25).

In her spiritual diary, through her role as a mystic at the service of black -Catholic women, sister Ursula recreates the system of solidarity that is the founding principle of cofradias but is jeopardized. Sister Ursula is familiar with cofradías since she founded the cofradía of Santa Carmen (Van Deusen, The Souls 37). By advocating for solidarity amongst descendants of Africans, sister Ursula also proposes an imagined Christian community for whom she serves as an intermediary to God. According to Benedict Anderson, who coins this term while analyzing the birth of nationalism in American colonies, people who perceive themselves as part of a group create "imagined communities". Anderson argues that the members of a community do not need to all know each other to still feel part of the same group; while their actual relationships might be defined by inequality and exploitation, they envision their community as a horizontal relationship of partnership and comradeship (5-7). In her imagined community detailed in her spiritual diary, sister Ursula redefines the conflicted relationships between black Catholic women that prevail around her, even in religious spaces such as convents and cofradías. To replace them, she offers a new black Catholic imagined community with members who 
share three elements: their service to God as black women, their desire for salvation, and their lack of access to the conventional economy of salvation.

Sister Ursula's imagined community includes fellow servants who approach her for help in the convent, such as the mulata who enters the kitchen "upset because each time her owner's mother came, she mistreated and chastised her, lying to her daughter about her" or Florencia Bravo, the tawdry mulata who pleases God so much (Van Deusen, The Souls 91, 94). It also encompasses the dead morena who she entrusts to God (The Souls 110) and the living morena Luisa who comes asking for her incarnation (The Souls 82). And finally, it is also composed of the black women who call her for guidance during her final hours of life, and the multiple black women who contact her from purgatory to lessen their stay there (The Souls 100, 125). By serving both, the dead and the living black Catholic women, sister Ursula creates an imagined community that transcends into the afterlife. She also proposes a model where all good Afro-Christian women form one community, working together, and practicing service, support, and solidarity for each other.

Although sister Ursula's imagined community is characterized by inclusion and solidarity amongst all good Christians from African descent, her work at the service of a more equal economy of salvation focuses on black Catholic women. Her focus on women is evident when examining the gender of those requesting her assistance. While it is logical that the black Catholics who come to her in the convent are all female since she lives in a community of women, it makes less sense that only black Catholic women request her intervention from purgatory. In contrast, from within the white population, both male and female individuals seek her help. Considering that the evolution of an individual's mystical experience is linked to the individual's dialectical relation to society, Ursula's identity might explain this gender difference. As a black Catholic woman, her mysticism concentrates on working against the marginalization of those members who are closest to her, that is, black women.

When considering sister Ursula's special service to black Catholic women, it is also important to realize that the male ecclesiastical institution conceives purgatory as a masculine space since its creation at the start of the Middle Ages (Mártinez i Alvarez 47). Sister Ursula's work on behalf of black women also redefines purgatory in gender terms. Because the imagined community she proposes particularly advocates for the solidarity between God serving women of African descent, she promotes a more feminine vision of purgatory as an afterlife space that treats not only people of different skin colors equally, but also men and women.

Sister Ursula's biographical account is therefore quite unique, not only because it is the first known-to-date spiritual diary dictated by a black Catholic woman in colonial Spanish-America, but also because it reveals the ability of an Afro-Latin American donada, who was born a slave, to use the spiritual writing imposed onto her by her confessor as a space of negotiation vis à vis the dominant criollo male ecclesiastical culture. While it is clear that sister Ursula does not have full agency over the production, transcription, and framing of her spiritual life into a vida, a close analysis also reveals that she is able to use her text to propose an alternate definition of black religious exemplarity, as well as a more empowered black Catholic community, and an alternative model of economy of salvation. In doing so, the AfroPeruvian donada follows the example set by some Spanish and criolla nuns who appropriated a form of writing meant to regulate their religiosity and redefined it as a space of empowerment. However, instead of using her spiritual diary to only negotiate her individual identity as a black Catholic woman in a subaltern position, she ultimately crafts it to propose more equal relations between those in power, usually Spaniards and criollos, and black Catholics as well as between men and women through an alternative economy of salvation. 


\section{NOTES}

1. I would like to extend my thanks to the anonymous reviewers of PALARA and Diane Niebylski for their comments and sugestions on previous versions of this article.

2. A high number of female slaves were present inside convents. Indeed, when wealthy women entered the convent, they often took with them a female slave (Burns 115).

3. Ursula had several confessors. The first one was the Jesuit Miguel de Salazar. He was most likely the one who first ordered her to record her visions. Considering the different types of penmanship present in the spiritual journal, it appears that several nuns wrote down what sister Ursula dictated to them. For more information, please see Van Deusen, The Souls, pp. 4-5.

4. Parts of her diary have survived and can be found today in Lima's Monastery of Santa Clara.

5. To my knowledge only two black Catholic women left writings about their spiritual lives in Latin America. The African born Maria Egipciaca da Vera Cruz (ca 1719 - ca 1765) was the second one. For more information, see McKnight, Afro, pp. 202.

6. In 1997, Alicia Wood compared Ursula's narrative to those that criollo male clerics wrote about her and about Estephania, another religious woman of color in colonial Lima. In 2004, Nancy Van Deusen published an outstanding edited translation of Ursula's spiritual autobiography as well as a later article examining how, despite her identity as an Afro-Peruvian slave, Ursula was able to become such a highly respected mystic in colonial Peru. And finally, in 2013 Larissa Brewer-García considered Ursula's spiritual diary as an example of the emergence of a discourse of "sacred blackness" in Limeño seventeenth-century society. A number of commendable studies have appeared examining the autobiographical and biographical narratives of/about nuns and female mystics as well as their complicated relationships with the Church and their confessors. For additional examples of representative works in the field of spiritual life writings, see Arenal and Schlau; Lavrin; Ludmer; Myers; Van Deusen; Schlau (1998 and 2013) and Weber.

7. At that time, race was much more fluid and was articulated in terms of "lineage" and "calidad" rather than as a fixed biological marker as it would become during the nineteenth century. See Carrera, pp. 6.
8. Vidas were spiritual autobiographies carefully crafted around the act of confession. These writings, which were often scrutinized by the women's confessors, also became discursive spaces for these women to build themselves as religious heroines. See McKnight, The Mystic, pp. 29-33.

9. For an excellent study of Saint Teresa of Avila, see Weber.

10. As Ludmer has explained in her "Respuesta a Sor Filotea", Sor Juana uses this combination of words to be able to write from her subaltern situation. Because she was a woman responding to a male superior, Sor Juana constantly represents herself as a subject who "does not know how to say" or "does not know what to say". See pp. 47-54.

11. This quote is a translation provided by Van Deusen. In this article, all quotes of Ursula's vida come from her edition. The original unabridged text dictated by Ursula in Spanish can also be accessed online at: http:// www.benditasalmas.org/admin/files/Ursula\%2ode\%20 Jesus\%2odiario.pdf.

12. Religious women writers often used this rhetoric, including Saint Teresa of Avila.

13. Most Spaniards and criollos perceived Africa as a land full of monstrous animals and people. Because Africans lived in such a monstrous land, Spaniards and criollos also considered them "savage pagans" at the Devil's service. For more information, see Gómez pp. 146; and Fra-Molinero, La imagen, pp. 6-7.

14. That explanation was based on a reading of the Ninth book of Genesis. See v. 21-28.

15. For more information, please see Olsen pp. 110-121. This idea is also present in the spiritual biographies of two other Afro-descendent religious women: sister Juana Esperanza and sister Chicaba Teresa. See Paniagua pp. 60 and pp. 100 and Gómez de la Parra pp. 311-314. For more information about black-Catholics workship, see Graubart and O'Toole.

16. The original quote reads "un negrillo abominable". The translation into English is mine.

17. Another possible reading of this quote points to a sort of "internalized oppression". Indeed, the first sentence, which establishes that sister Ursula is surprised that 
an Afro-Peruvian woman who had "not lied or stolen" had gone to Purgatory implies that she thought that she was a good Christian and should have gone to Paradise. However, the following sentence explains that the woman went to purgatory "because of her character, and because she slept and ate at the improper times", which reflect that her lack of obedience and proper slave conduct was perceived as sinful.

18. "Limpieza de sangre" referred to the concept of "purity of blood". In the Covarruvias dictionary, "limpio" is defined as "old Christian, free of Jewish or Muslim blood" (my translation). Converted women of African heritage, such as Ursula, therefore did not satisfy the requirement of "limpieza de sangre".
19. A beata was a lay pious woman who took informal religious vows. See Van Deusen, The Souls pp. 194.

20. The translation of this title from Spanish into English is mine as well as the quote that follows.

21. Van Deusen reaches a similar conclusion. She proposes that by empowering the marginalized subjects of the convent and making them actors of her visions, Ursula was making them central actors at the level of the convent, Lima, and colonial Peru. For more information, see Van Deusen, The Souls pp. 56.

\section{WORKS CITED}

Anderson, Benedict. Imagined Communities: Reflections on the Creation and Spread of Nationalism. Verso, 1991.

Arenal Electa and Stacey Schlau. "Stratagems of the Strong, Stratagems of the weak: Autobiographic Prose of the Seventeenth-Century Hispanic Convent." Tulsa Studies in Women's Literature vol.9, Spring 1990, pp. 25-42.

Black Christopher and Pamela Gravestock. Early Modern Confraternities in Europe and the Americas: International and Interdisciplinary Perspectives. Ashgate, 2006.

Bowser, Frederick. The African Slave in Colonial Peru 15241650. Stanford UP, 1974.

Brewer-García, Larissa. "Beyond Babel: Translation of Blackness in Colonial Peru and New Granada." U of Pennsylvania P, 2013.

Burns, Catherine. Colonial Habits: Convents and the Spiritual Economy of Cuzco, Peru. Duke UP, 1999.

Carrera, Magali M.. Imagining Identity in New Spain: Race, Lineage, and the Colonial Body in Portraiture and Casta Painting. U of Texas P, 2003.

Córdoba y Salinas, Diego de. Corónica de la religiosísima provincia de los doze apóstoles del Peru de la orden de nuestro seráfico PS Francisco de la regular observancia. Jorge López de Herrera, 1651.

Corilla Melchor, Ciro. "Cofradías en la ciudad de Lima: Siglos XVI y XVII. Racismo y conflictos.” Etnicidad y discriminación racial en la historia del Perú. Fondo Editorial de Pontificia Universidad Católica del Perú, 2002, pp. 11-34.

Donahue, Darcy. "Writing Nuns' Lives." Journal of Hispanic Philology vol 13, Fall-spring 1988-89, pp. 230-239.

Fogelman, Patricia. "Una 'economía espiritual de la salvación': Culpabilidad, purgatorio y acumulación de indulgencias en la era colonial.” Andes 15, 2004, pp. 55-86.

Fra-Molinero, Baltasar. La imagen de los negros en el teatro del Siglo de Oro. Siglo Veintino de España Editores, 1995.
Gómez, Alejandro. "El estigma africano en los mundos hispano-atlánticos (siglos XIV al XIX).” Revista de historia vol. 153, 2005, pp. 139-179.

Gómez de la Parra, José. Fundación y primero siglo: crónica del primer convento de Carmelitas descalzas en Puebla. 16041704. Universidad Iberoamericana, 1992.

Graubart, Karen. "So Color De Una Cofradia: Catholic Confraternities and the Development of Afro-Peruvian Ethnicities in Early Colonial Peru." Slavery and Abolition vol. 33, no.1, March 2012, pp. 43-64.

Gruzd, Anatolye, Bary Wellman and Yuri Takhteyev. "Imagining Twitter as an Imagined Community." American Behavioral Scientist vol. 55, 2011, pp. 1294-1318.

Gunnarsdóttir, Ellen. Mexican Karismata: The Baroque Vocation of Francisca de los Ángeles 1674-1744. U of Nebraska P, 2004.

Jaffary, Nora. "La percepción de clase y casta en las visiones de los falsos místicos en el México Colonial. Signos históricos vol. 8, July-December 2002, pp. 61-88.

Lachance, Paul. "Mysticism and Social Transformation according to the Franciscan Way." Mysticism and Social Transformation, edited by Janet Ruffing, Syracuse UP, 2001, pp. 55-75.

Lavrin, Asunción. Brides of Christ: Conventual Life in Colonial Mexico. Stanford UP, 2008.

Lockart, James. "Social Organization and Social Change in Colonial Spanish America." The Cambridge History of Latin America. Vol. 3. Ed. Lesley Bethell. Cambridge UP, 1984, pp. 265-320.

Ludmer, Josefina. "Las tretas del débil." La sartén por el mango, edited by Patricia Elena Gonzalex, Ediciones Huracán, 1984, pp. 47-54. 
Martinez i Alvarez, Patricia. "Mujeres religiosas en el perú del siglo XVII.” Revista complutense de historia de América vol. 26, 2000, pp.27-56.

McKnight, Kathryn and Leo Garafalo (eds.). Afro-Latino Voices: Narratives from the Early Modern Ibero-Atlantic World, 1550-1812. Hackett Publishing, 2009.

_-_. The Mystic of Tunja: The Writings of Madre Castillo 16711742. U of Massachusetts P, 1997.

Medina, Bernardo. Medina, Bernardo de, (O.P.). Vida Prodigiosa Del Venerable Siervo De Dios Fr. Martin De Porras, Natural De Lima, De La Tercera Orden De N.P. Santo Domingo. Domingo Garcia Morràs ..., 1675.

Myers, Kathleen, 'Crossing Boundaries: Defining the Field of Female Religious Writing in Colonial Latin America'. Colonial Latin American Review vol. 9, no. 2, 2000, pp.151-65.

Olsen, Margaret. Slavery and Salvation in colonial Cartagena de Indias. U of Florida P, 2004.

O'Toole, Rachel Sarah. Bound Lives: Africans, Indians, and the Making of Race in Colonial Peru. U of Pittsburgh P, 2012.

Paniagua, R.P. don Juan Carlos Miguel de. Compendio de la vida ejemplar de la Venerable Madre Sor Teresa Juliana de Santo Domingo, tercera profesa en el convento de Santa María Magdalena, vulgo de la Penitencia, Orden de Santo Domingo, de la ciudad de Salamanca. 2nd ed. Eugenio de Honorato y San Miguel, impresor de la dicha ciudad y Real Universidad, 1764.

Rodríguez Nobrega, Janeth. "El purgatorio en la pintura barroca venezolana: iconografía y discurso.” Escritos en arte, estética y cultura vol. 21-22, 2005, pp. 189-208.

Ruffing, Janet. "Introduction."Mysticism and Social Transformation. Syracuse UP, 2001, pp. 1-28.

Saint Teresa of Avila. The Collected Works of St. Teresa of Avila, translated by Kieran Kavanaugh, Institute of Carmelite Studies Publications, 1985.

Sánchez-Concha, Rafael. "Los santos y las concepciones políticas y sociales en el Perú virreinal.” América Hispania Sacra vol. 54, 2002, pp. 315-328.

Sánchez Rodríguez, Susy. "Un Cristo moreno "conquista” Lima: Los arquitectos de la fama pública del Señor de los Milagros (1651-1771)." Etnicidad y discriminación racial en la historia del Perú, edited by Ana Cecilia Carrillo, Fondo editorial de la Pontificia Universidad del Perú, 2002, pp. 65-92.

Sandoval, Alonso. Treatise on Slavery: Selections from De instauranda Aethiopum salute. Ed. and trans. Nicole Von Germeten. Hackett Publishing Company, 2008.

Tardieu, Jean Pierre. Los negros y la iglesia en el Perú, siglos XVI-XVII. Centro Cultural Afroecuatoriano, 1997.

Van Deusen, Nancy. "Reading the Body: Mystical Theology and Spiritual Actualisation in Early Seventeenth-Century Lima”. Journal of Religious History vol. 33, no. 1, 2009, pp. $1-27$.
- _ _. The Souls of Purgatory: The Spiritual Diary of a Seventeenth-Century Afro-Peruvian Mystic, Ursula de Jesús. $\mathrm{U}$ of New Mexico P, 2004.

_ _ _. "Ursula de Jesus: A Seventeenth-Century AfroPeruvian Mystic." The Human Tradition in Colonial Latin America, edited by Kenneth J. Adrien,. Royman \& Littlefield Publishing Group, 2013, pp. 88-103.

Vega, Walter. “Cofradías en el Perú colonial: una aproximación bibliográfica.” Diálogos vol.1, 1999), pp.137- 151.

Velázquez Gutierrez, María Elisa. Mujeres de origen africano en la capital novohispana. Siglos XVII y XVIII. Instituto Nacional de Antropología e Historia, 2006.

Von Germeten, Nicole. “Introduction”. Treatise: Selections from De Instauranda Aethiopum salute, edited and translated by Nicole Von Germeten, Alonso de Sandoval. Hackett Publishing Company, 2008, pp. ix-xxx.

Weber, Alison. Teresa of Avila and the Rhetoric of Femininity. Princeton UP, 1990.

Wood, Alicia. "Chains of virtue: Seventeenth-Century Saints in XVII Century Lima.” Diss. Rice University, 1997.

Woods, Richard. "Mysticism and Social Action: the mystic's calling, development and social activity." Journal of Consciousness Studies vol. 3, no 2, 1996, pp. 158-171. 